\title{
ALGUMAS CONSIDERAÇÕES INICIAIS SOBRE A OBRA THE GROUND OF ARTES, DE ROBERT RECORDE
}

\section{SOME INITIAL REMARKS ON THE WORK THE GROUND OF ARTES, BY ROBERT RECORDE}

\author{
Isabelle Coelho da Silva ${ }^{1}$ \\ Pontifícia Universidade Católica de São Paulo \\ Fumikazu Saito ${ }^{2}$ \\ Pontifícia Universidade Católica de São Paulo
}

\begin{abstract}
Resumo
Este trabalho faz parte de pesquisa de doutorado em história da matemática, que está em desenvolvimento e tem por objetivo apresentar alguns apontamentos realizados durante uma leitura preliminar de um tratado dedicado ao ensino de aritmética, intitulado: The Ground of Artes, publicado pela primeira vez em 1543, por Robert Recorde (15101558). Esse tratado, que foi revisto e ampliado diversas vezes ao longo dos séculos XVI e XVII, traz o registro dos conhecimentos aritméticos que transitaram naquela época. Em uma primeira leitura, pôde-se perceber que essa obra aborda temas relacionados à aritmética prática, voltados, principalmente, para a instrução de comerciantes. Ela trata de números e de frações, bem como das operações básicas de aritmética, porém orientadas para a realização de cálculos ordinários ligados à conversão de pesos e medidas. Por meio desse estudo preliminar, pôde-se levantar algumas hipóteses que ajudaram a definir algumas condições de contorno que deverão nortear futuras investigações sobre o contexto de elaboração desse tratado, bem como a análise contextual e epistemológica da aritmética inglesa e o seu ensino no século XVI.
\end{abstract}

Palavras-chave: The Ground of Artes; Robert Recorde; História da Matemática; Ensino.

\section{Abstract}

This work is part of a doctoral research in history of mathematics that is under development and aims to present some remarks carried out during a preliminary reading of a treatise dedicated to the teaching of arithmetic, entitled: The Ground of Artes, published for the first time in 1543, by Robert Recorde (1510-1558). This treatise, which was revised and extended several times throughout the 16th and 17th centuries, brings the record of the arithmetical knowledge that transited at that time. In a first reading, it was possible to see that this work deals with themes related to practical arithmetic, focused mainly on the instruction of merchants. It deals with numbers and fractions, as well as basic arithmetic operations, but they were oriented towards ordinary calculations related to the conversion of weights and measures. Through this

\footnotetext{
1 isabellecoelhods@gmail.com
}

2 fsaito@pucsp.br

Número Especial - IV Seminário Cearense de História da Matemática

Boletim Cearense de Educação e História da Matemática - Volume 07, Número 20, 312 - 322 (2020)

DOI: $10.30938 /$ bocehm.v7i20.2816 
Algumas considerações iniciais sobre a obra The Ground of Artes, de Robert Recorde

Isabelle Coelho da Silva e Fumikazu Saito

preliminary study, it was possible to raise some hypotheses that helped to define some boundary conditions that will guide future investigations about the context of elaboration of this treatise, as well as the contextual and epistemological analysis of the English arithmetic and its teaching in the 16th century.

Keywords: The Ground of Artes; Robert Recorde; History of Mathematics; Teaching.

\section{Introdução}

A preocupação com o ensino da matemática é um tema bem antigo e ganhou impulso em meados do século XVI em virtude da nova ordem social, política, econômica e religiosa, que se instaurou no Ocidente Latino a partir do Renascimento. Especificamente, no que diz respeito às ilhas britânicas, as matemáticas, tanto aquelas que compunham o quadrivium medieval (isto é, geometria, astronomia, aritmética, música), quanto o rol de artes ligadas à navegação, à agrimensura, à arquitetura, à artilharia, entre muitas outras, passaram a ser valorizadas não só por razões práticas, mas também teóricas. ${ }^{3}$ Isso é notório pelo grande número de publicações dedicadas aos vários domínios do saber matemático. A partir do século XVI, ao lado dos tradicionais compêndios e tratados matemáticos, foram publicados toda sorte de obras e estudos dedicados às geometrias e aritméticas práticas, bem como à mecânica, à navegação, à arquitetura, aos instrumentos etc.

Muitos desses tratados e estudos, entretanto, não tinham apenas o objetivo de disseminar o saber matemático, mas também de ensiná-lo. Um desses tratados, que recebeu grande atenção dos ingleses no século XVI, foi The Ground of Artes, publicado pela primeira vez por Robert Recorde (1510-1558), em 1543. Esse autor, que nasceu em 1510, na cidade de Tenby, País de Gales, destacou-se por se preocupar com o ensino de matemática. Ele escreveu uma série de seis livros, dos quais apenas quatro sobreviveram. The Ground of Artes (1543) foi o primeiro dessa série, seguido de The Pathwaie to Knowledge (1551), The Castle of Knowledge (1556) e The Whetstone of Witte (1557). Os outros dois livros, um deles intitulado The Gate to Knowledge (15[?]), não foi publicado e outro, The Treasure of Knowledge (15[?]), não foi finalizado (FAUVEL, 1989).

Pode-se dizer que The Ground of Artes foi a primeira obra dedicada às matemáticas, publicada por Recorde. Trata-se de uma obra sobre aritmética que, segundo Easton (1967), era a mais conhecida e disseminada entre os ingleses do século

${ }^{3}$ A esse respeito, consulte estudos de: Debus (1978), Rossi (1989, 2001).

Número Especial - IV Seminário Cearense de História da Matemática

Boletim Cearense de Educação e História da Matemática - Volume 07, Número 20, 312 - 322 (2020)

DOI: 10.30938/bocehm.v7i20.2816 
Algumas considerações iniciais sobre a obra The Ground of Artes, de Robert Recorde

Isabelle Coelho da Silva e Fumikazu Saito

XVI. Além de ser um dos primeiros textos escritos em língua inglesa, a autora afirma que parte da sua fama se devia à influência do próprio Recorde e de John Dee (15271608), cujas versões, a partir de 1561, foram aumentadas e revisadas por ele.

Tendo isso em vista, este trabalho tem por objetivo apresentar alguns apontamentos realizados durante uma primeira leitura de The Ground of Artes. Por meio desse estudo, busca-se realizar um mapeamento preliminar de alguns conhecimentos aritméticos, que transitaram naquela época, para se proceder, em um momento posterior, a uma análise contextual e epistemológica sobre a aritmética inglesa e o seu ensino no século XVI. Para tanto, devido à disponibilidade de acesso e estado de conservação do material, selecionou-se a versão publicada em 1648, cujo frontispício indica que foi escrita por Recorde, revista por John Dee, ampliada por John Mellis e, então, corrigida, ilustrada e expandida por Robert Hartwell.

\section{The Ground of Artes, de Robert Recorde}

A ampla repercussão que teve The Ground of Artes é evidenciada pelo número de edições que recebeu. A primeira edição conhecida é datada de 1543 e faz parte do acervo do Museu Britânico. Nos anos subsequentes, o texto de Recorde foi reimpresso diversas vezes. Easton (1967) afirma que sobreviveram 15 versões publicadas até o ano de 1600 , das quais ela cita 10 para fazer o estudo de seu conteúdo: $1543 ; 1545$ ? $^{4} ; 1558$; $1561 ; 1566 ; 1570 ; 1571 ; 1573 ; 1575 ;$ e 1579.

Embora alguns autores mencionem a possibilidade de haver uma outra versão anterior a de 1543, sua existência, entretanto, não foi comprovada (CAJORI, 1922; BARON, 1966). A esse respeito, Easton (1967) afirma que outra versão, que não possui indicação do ano de publicação e que os estudiosos, inicialmente, acreditavam ser de 1542?, foi redatada para 1545?, devido à comparação das letras e dos ornamentos com outros livros do mesmo impressor ${ }^{5}$. Essa autora, também, aponta versões de 1540, 1549 e 1551, que foram mencionadas em textos antigos, mas que, caso tenham existido, não sobreviveram.

Por meio desses estudos, pode-se dizer que a última versão escrita e organizada, inteiramente, pelo próprio Recorde foi a de 1558, que, atualmente, faz parte do acervo

\footnotetext{
${ }^{4} \mathrm{O}$ ponto de interrogação é utilizado para indicar a incerteza em relação ao ano exato de publicação da obra, o que não foi expresso pelo autor nessa versão e foi definido a partir de evidências históricas.

5 As edições dessa obra publicadas até o ano de 1575 foram impressas por Raynold Wolfe (EASTON, 1967).
} 
da Universidade Columbia, em Nova York. Antes dessa edição, tinha sido lançado um protótipo dele em 1552, que se encontra hoje depositado no Museu Britânico. Desse modo, segundo Easton (1967), foi, a partir da impressão de 1558, que outros autores, como John Dee (1527-1608), elaboraram as publicações revisadas, comentadas e aumentadas de The Ground of Artes. Assim, desde 1558, surgiram outras edições do mesmo tratado, tais como as de 1648, 1652 e 1699. Essas três versões, entretanto, receberam acréscimos de outros estudiosos que lhe acrescentaram uma terceira parte. Como se pode constatar no Quadro 1, na edição de 1648, as duas primeiras partes correspondem aos dois primeiros diálogos que foram escritos e organizados por Recorde. A terceira parte, como o próprio título dessa versão afirma, foi escrita, organizada e acrescida à obra original por John Mellis.

\section{O conteúdo presente na obra}

Um breve panorama sobre os assuntos abordados em The Ground of Artes já pode ser percebido no seu frontispício (Figura 1). Na edição de 1648, a obra traz o título Records Arithmetick or, The Grovnd of Arts, cuja tradução poderia ser Aritmética de Recorde ou O Fundamento das Artes ${ }^{6}$.

\footnotetext{
6 "Naquela época, "arte" (ars) tinha um sentido mais lato, ligado à prática e à experiência, visto que esse termo designava as artes mecânicas e ao trabalho manual em oposição às artes liberais (em essência, voltada à reflexão teórica)" (SAITO, 2015, p. 163).
} 


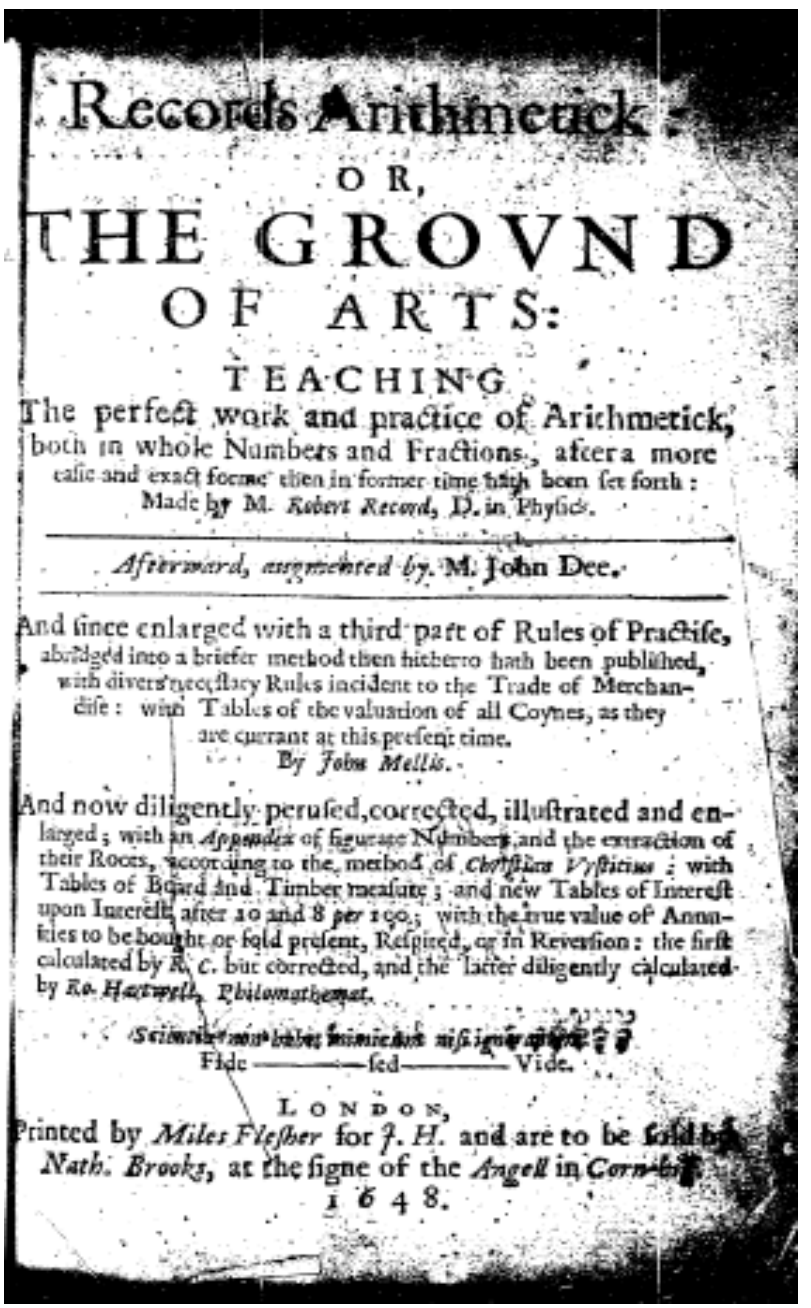

Figura 1 - Frontispício da edição de 1648 de The Ground of Artes. Fonte: Recorde (1648).

Em seguida, no frontispício, pode-se ver uma breve descrição sobre os assuntos tratados na obra, que é um recorte daquela escrita por Recorde nas primeiras versões. Aqui, consegue-se notar que a obra tinha o propósito de organizar e sistematizar a aritmética prática, visto que propõe "Ensinar o perfeito emprego e prática da Aritmética dos Números inteiros e Frações de uma forma mais fácil e exata do que fora estabelecido anteriormente". Apelativo, o título da obra anuncia uma nova forma, "mais fácil e exata", de resolver problemas aritméticos do que fora, até então, ensinada. Além disso, reflete a preocupação de Recorde com questões de ordem prática, o que é confirmado por Broadbent (1947), que observa que a obra trata de conteúdos práticos da aritmética.

Isso é notório nos capítulos que compõem a obra. Uma visão mais detalhada do que é abordado, nessa edição, pode ser constatada no sumário, que foi nomeado pelo autor de Tabela de todo o Conteúdo desse livro (Quadro 1). Embora não exista a 
Algumas considerações iniciais sobre a obra The Ground of Artes, de Robert Recorde

Isabelle Coelho da Silva e Fumikazu Saito

demarcação de linhas no original, elas foram utilizadas, aqui, para melhor visualização, sendo o texto e as páginas indicadas pelo autor permanecidos iguais, incluindo as diferenças de escrita de algumas palavras.

Quadro 1 - Conteúdo de The Ground of Artes (1648).

\begin{tabular}{|c|c|}
\hline $\begin{array}{l}\text { Here followeth a Table of the whole Contents of this Book. } \\
\text { The Contents of the first Dialogue. }\end{array}$ & \\
\hline The declaration of the profit of Arithmeticke. & Page 1 \\
\hline Numeration, with an easie and large Table. & p. 10 \\
\hline Addition. & p.27 \\
\hline Substraction. & p.46 \\
\hline Multiplication. & p.69 \\
\hline Division. & p.87 \\
\hline $\begin{array}{l}\text { Reduction, with divers declarations of Coynes, Weights and Measures of sundry formes newly } \\
\text { added, with a new Table, containing most part of the gold Coyne throughout Christendome, with } \\
\text { the true weight and valuation of them now in currant English-money. }\end{array}$ & p. 120 \\
\hline Progression both Arithmeticall and Geometricall, with divers sundry questions touching the same. & p.141 \\
\hline The Golden Rule, or Rule of Proportion called the Rule of Three direct. & p.174 \\
\hline The Backer Rule of three, with divers questions thereunto belonging, newly added and augmented. & p.180 \\
\hline The double Rule of Proportion direct. & p.194 \\
\hline The Rule of Proportion composed of five numbers. & p.194 \\
\hline The Backer Rule, or second part of the Rule of Proportion, composed. & p.198 \\
\hline The Rule of Fellowship without time, limited. & p.202 \\
\hline The Rule of Fellowship with time limited. & p.210 \\
\hline \multicolumn{2}{|l|}{ The second Dialogue containeth } \\
\hline The first five kinds of Arithmetick wrought by Counters. & p.217 \\
\hline The common kinds of casting by Counters, after the Merchants fashion, and Auditors also. & p.257 \\
\hline \multicolumn{2}{|l|}{ The Contents of the second part touching Fractions. Page 261.} \\
\hline Numeration in Fractions. & p.264 \\
\hline The order of working Fractions. & p.270 \\
\hline Reduction of divers Fractions into one denomination in three varieties. & p.272 \\
\hline Reduction of Fractions of fractions. & p.270 \\
\hline Reduction of improper Fractions. & p.280 \\
\hline $\begin{array}{l}\text { Reduction of Fractions to the smallest denomination, with easie Rules how to convert them } \\
\text { thereunto. }\end{array}$ & p.285 \\
\hline $\begin{array}{l}\text { Reduction of a Fraction, and how it may be turned into any other Fraction, or into what } \\
\text { denomination you lift. }\end{array}$ & p.290 \\
\hline Addition of Fractions. & p.292 \\
\hline Substraction of Fractions. & p.295 \\
\hline Multiplication of Fractions. & p.298 \\
\hline Duplation of Fractions. & p.304 \\
\hline Division of Fractions. & p.305 \\
\hline Mediation of Fractions. & p.311 \\
\hline The Golden Rule direct in Fractions. & p.311 \\
\hline The Backer, or reverse Rule in Fractions. & p.315 \\
\hline $\begin{array}{l}\text { The Statute of Assise of Bread an Ale recognized, and applied to this time, with new Tables } \\
\text { thereunto annexed. }\end{array}$ & p.318 \\
\hline The Statute of measuring of ground, with a Table threof, faithfully calculated and corrected & p.330 \\
\hline The Rule of Fellowship, or society, with the reasons of the Rules, and proofs of their work. & p.336 \\
\hline To finde three numbers in any proportion. & p.349 \\
\hline
\end{tabular}




\begin{tabular}{|c|c|}
\hline $\begin{array}{l}\text { The Rule of Alligation, with divers questions, and the proofs of their works, with many varieties of } \\
\text { such solutions. }\end{array}$ & p.353 \\
\hline The Rule of Falshood, of false Position, with divers questions, and their proofs. & p.370 \\
\hline \multicolumn{2}{|l|}{ The Contents of the third part. } \\
\hline $\begin{array}{l}\text { The } 1 \text { Chapter entreateth of Rules of Brevity and practise, after a briefer method then hitherto hath } \\
\text { been published in the English tongue. }\end{array}$ & p.411 \\
\hline $\begin{array}{l}\text { The } 2 \text { Chapter entreateth of brief Reduction of divers measures, as Els, Tards, Braces, \&c. by rules } \\
\text { of practise. }\end{array}$ & p.447 \\
\hline $\begin{array}{l}\text { The } 3 \text { Chapter entreateth of the Rule of Three in broken mumbers, after the trade of Merchants, } \\
\text { something differing from M. Records order, which is comprehended in three Rules. }\end{array}$ & p.451 \\
\hline The 4 Chapter entreateth of losse and gain in the trade of Merchandise. & p.468 \\
\hline $\begin{array}{l}\text { The } 5 \text { Chapter entreateth of losse and gain in the trade of Merchandise upon time, \&c. with } \\
\text { necessary questions therein wrought by double rule of Three, or the rule of proportion composed } \\
\text { of } 5 \text { numbers. }\end{array}$ & p.476 \\
\hline $\begin{array}{l}\text { The } 6 \text { Chapter entreateth of Rules payment, and one of the necessariest rules that appertaineth to } \\
\text { buying and selling \&c. }\end{array}$ & p.476 \\
\hline $\begin{array}{l}\text { The } 7 \text { Chapter entreateth of buying and selling in the trade of Merchandise, wherein is taken part } \\
\text { ready mony, and divers days of payment given for the reft, and what is won and lost in the } \\
\text { hundred pound forbearance for twelve moneths. }\end{array}$ & p.482 \\
\hline $\begin{array}{l}\text { The } 8 \text { Chapter entreateth of Tare and allowances of Merchandise, sold by weight, and of their } \\
\text { losses \& gains therein, \&c. }\end{array}$ & p.488 \\
\hline $\begin{array}{l}\text { The } 9 \text { Chapter entreateth of lengths and breadths of Arras, and other clothes, with divers questions } \\
\text { thereunto belonging. }\end{array}$ & p.492 \\
\hline The 10 Chapter entreateth of reducing of pawnes of Geanes into English yards. & p.497 \\
\hline The 11 Chapter entreateth of Rules of Loan and Interest, with divers questions incident thereunto. & p.498 \\
\hline The 12 Chapter entreateth of the making of Factors. & p.503 \\
\hline $\begin{array}{l}\text { The } 13 \text { Chapter entreateth of rules of barter or exchange of Merchandise, wherein is taken part } \\
\text { ware and part ready money, with their proofs, and divers other necessary questions thereunto } \\
\text { belonging. }\end{array}$ & p.508 \\
\hline $\begin{array}{l}\text { The } 14 \text { Chapter entreateth of exchanging of money from one place to another, with divers } \\
\text { necessary questions incident thereunto. }\end{array}$ & p.521 \\
\hline $\begin{array}{l}\text { The } 15 \text { Chapter entreateth of six sundry formes of practises for reduction of English, Flemish, and } \\
\text { French money, and how each of them may easily be brought to money sterling. }\end{array}$ & p.530 \\
\hline $\begin{array}{l}\text { The } 16 \text { Chapter containeth a brief note of the ordinary Coynes of most places of Christendom for } \\
\text { traffick, and the manner of their exchanging from one City or Town to another, which known, the } \\
\text { Italians call Parie: whereby they find the gain or losse upon the Exchange. }\end{array}$ & p.537 \\
\hline $\begin{array}{l}\text { The } 17 \text { Chapter containeth also a declaration of the diversity of weights and measures of most } \\
\text { places in Christendom for traffique, proportinated in equality one to another, as also unto our } \\
\text { English measure and weight, whereby the ingenious practitioner may easily reduce the weight and } \\
\text { measure of each Country into another. }\end{array}$ & p.542 \\
\hline The 18 Chapter entreateth of divers sports and pastimes, done by Number. & p.552 \\
\hline An Appendix of figurate Numbers, with the extraction of roots. & p.559 \\
\hline A table of board and timber measure by Robert Hartwell. & p.585 \\
\hline Certaine tables of interest at 10 per 100. & p.590 \\
\hline New tables of interest at 8 per 100. & p.603 \\
\hline
\end{tabular}

Fonte: Recorde (1648).

Cabe, aqui, observar que, nesse quadro, apenas a primeira e a segunda partes foram elaboradas por Recorde. A terceira parte, como mencionado anteriormente, foi escrita, posteriormente, por Mellis. A primeira parte trata dos números inteiros, das 
Algumas considerações iniciais sobre a obra The Ground of Artes, de Robert Recorde

Isabelle Coelho da Silva e Fumikazu Saito

quatro operações aritméticas (adição, subtração, multiplicação e divisão), progressão geométrica e aritmética, regra de três (golden rule), regra da proporção inversa (backer rule), a regra da proporção composta (double rule) e a "regra da comunhão" (rule of fellowship), usada para calcular a divisão de lucros.

Da mesma forma, a segunda parte da obra trata das quatro operações (adição, subtração, multiplicação e divisão) de frações, bem como da regra de três (golden rule), da regra da proporção inversa (backer rule), da "regra da comunhão" (rule of fellowship) e de outras duas regras, a da "alocação" (rule of alligation) e a da falsa posição (rule of falshood). Além disso, trata de outras operações com frações, tais como a redução ao denominador comum, redução de frações impróprias, entre outras.

Tomados em conjunto, pode-se dizer, pelos assuntos abordados nessas duas partes, que o tratado tinha em vista instruir comerciantes, pois, além das regras para a realização de cálculos ordinários, Recorde aborda, ainda, temas ligados a pesos e medidas, o que é notório na seção intitulada: "redução" (reduction), dedicada à conversão de pesos (weight), moedas (coin) e medidas (measures).

Essa ideia é, também, reforçada pelos assuntos tratados na terceira parte, escrita e anexada à obra original de Recorde por Mellis. Nessa parte, Mellis discorre sobre outras "regras práticas" que incluíam normas necessárias para o comércio de mercadorias, bem como a conversão de moedas, pesos e medidas de diferentes regiões. Desse modo, um primeiro exame desse tratado leva à conclusão de que The Ground of Artes estava em estreita relação com os chamados livros de ábaco, publicados a partir do século XIII, na Península Itália, que tinha o objetivo de treinar jovens comerciantes (ROQUE, 2012). Indícios a esse respeito foram, da mesma maneira, apresentados por Neal (2002), que afirma que, além dos temas abordados por Recorde em seu tratado, os livros de ábaco, similarmente, foram, também, escritos em forma dialogada. E eis, aqui, um ponto interessante que merece ser investigado posteriormente. $\mathrm{O}$ tratado, embora verse sobre aritmética prática, parece ter como alvo um público muito mais amplo.

\section{Considerações finais}

Embora Recorde tivesse formação universitária e, portanto, estava muito familiarizado com o latim, decidiu publicar esse tratado em inglês. Isso parece indicar que o tratado era não só dedicado aos comerciantes, mas também a um público leigo em aritmética. De fato, considerando que o conhecimento de aritmética, nas escolas de 
ábaco, era praticamente transmitido oralmente, é bem provável que The Ground of Artes tenha sido escrito para registrar e sistematizar os conhecimentos da aritmética prática. Contudo, a forma dialogada parece ter o propósito de "facilitar" o ensino de aritmética, uma vez que, como Recorde (1648) apontara no prefácio, “a carta ao leitor”, a cada dúvida do "estudioso" (scholar), o "mestre" (master) poderia respondê-la de forma ordenada. Isso levanta a hipótese de que essas duas escolhas, a escrita vernacular e dialogada, parecem estar relacionadas não só ao público-leitor desse tratado, isto é, àqueles que se dedicavam ao ofício de resolver problemas de ordem prática e já estavam familiarizados com os procedimentos da aritmética prática, mas também a uma técnica de ensinar aritmética ao leitor leigo.

Com efeito, dois fortes indícios apontam para essa direção. O primeiro se refere aos dois dialogantes no tratado. O diálogo é promovido entre "mestre" (master) e "estudioso" (scholar) e não entre "mestre" (master) e "aprendiz" (aprentice), como nas escolas de ábaco, de modo que, por "estudioso", provavelmente, Recorde se referia aos estudiosos de matemáticas, isto é, professores particulares, praticantes de matemáticas e o cristão virtuoso. O segundo indício diz respeito a outros tratados de mesma natureza que, outrora, haviam sido publicados na Inglaterra. De acordo com Howson (1982), o tratado do Recorde, embora fosse muito conhecido em sua época, não foi o primeiro e nem o mais importante livro de aritmética inglesa. Outros livros, escritos em latim e em inglês já circulavam entre os estudiosos de matemáticas. Mas, como observa Howson (1982), alguns desses livros não eram muito adequados à classe mercantil, visto que muitos estavam escritos em latim e eram lidos e estudados por eruditos nas universidades; e, outros, embora estivessem escritos em vernáculo, eram bastante prolixos e de difícil compreensão.

Desse modo, considerando-se os temas, os assuntos abordados em The Ground of Artes, bem como a sua forma e organização, é bem provável que esse tratado tenha sido escrito para atender a uma exigência não só comercial, mas também universitária, uma vez que o contexto inglês, daquele período, buscou reformar o ensino das artes liberais. $^{7}$ Essas e outras questões, que emergiram dessa leitura preliminar de The Ground of Artes, entretanto, serão posteriormente investigadas, tendo por foco a aritmética inglesa e seu ensino no século XVI. As hipóteses, aqui levantadas, ajudaram,

${ }^{7}$ Vide a esse respeito em Debus (1978), Howson (1982) e Karp e Schubring (2014). 
Algumas considerações iniciais sobre a obra The Ground of Artes, de Robert Recorde

Isabelle Coelho da Silva e Fumikazu Saito

assim, a definir algumas condições de contorno, que deverão nortear futuras investigações sobre o contexto de elaboração desse tratado.

\section{Referências}

BARON, M. E. A Note on Robert Recorde and the Dienes Blocks. The Mathematical Gazette, Leicester, v. 50, n. 374, p.363-369, 1966. Disponível em: <https://www.jstor.org/stable/3613932>. Acesso em: 06 set. 2019.

BROADBENT, T. A. A. (Ed.). The Ground of Artes. The Mathematical Gazette, Greenwich, v. 31, n. 295, p.1-2, jul. 1947. Disponível em: <https://www.jstor.org/stable/3610499>. Acesso em: 06 set. 2019.

CAJORI, F. Robert Recorde. The Mathematics Teacher, Reston, v. 15, n. 5, p.294302, 1922. Disponível em: 〈https://www.jstor.org/stable/27950425〉. Acesso em: 06 set. 2019.

DEBUS, A. G. El hombre y la naturaliza en el renacimiento. México: Fondo de Cultura Económica, 1978.

EASTON, J. B. The Early Editions of Robert Recorde's Ground of Artes. Isis, Chicago, v. 58, n. 4, p.515-532, 1967. Disponível em: <www.jstor.org/stable/228426>. Acesso em: 11 nov. 2019

FAUVEL, J. Platonic rhetoric in distance learning: how Robert Record taught the home learner. For the Learning of Mathematics, Montreal, v. 9, n. 1, p.2-6, 1989.

Disponível em: < http://www.jstor.org/stable/40247938>. Acesso em: 25 abr. 2019.

HOWSON, G. A history of matemathics education in England.Cambridge, London, New York: Cambridge University Press, 1982.

KARP, A.; SCHUBRING, G. Mathematics Education in Europe in Premodern Times. In: KARP, A.; SCHUBRING, G. (eds.). Handbook on the History of Matemathics Education. New York, Heidelberg, Dordrecht, London: Springer, 2014, p. 129-151.

NEAL, K. From discrete to continuous: The broadening of number concepts in Early Modern England. Dordrecht / Boston / London: Springer Science+business Media, 2002. $175 \mathrm{p}$.

RECORDE, R. The Ground of Artes. Londres: Reynold Wolff, 1552.

RECORDE, R. Records Arithmetick or, The Ground of Arts. Londres: Miles Flesher, 1648.

ROQUE, T. História da Matemática: Uma visão crítica, desfazendo mitos e lendas. Rio de Janeiro: Zahar, 2012. 
Algumas considerações iniciais sobre a obra The Ground of Artes, de Robert Recorde

Isabelle Coelho da Silva e Fumikazu Saito

ROSSI, P. Os filósofos e as máquinas, 1400-1700. São Paulo: Companhia das Letras, 1989.

ROSSI, P. O nascimento da ciência moderna na Europa. Bauru: Edusc, 2001.

SAITO, Fumikazu. História da matemática e suas (re)construções contextuais. São Paulo: Ed. Livraria da Física/SBHMat, 2015. 